\title{
The efficacy of topical camphorated oil in long-term care of residents with incontinence-associated dermatitis
}

\author{
Skuteczność miejscowego stosowania oleju kamforowego u pacjentów opieki \\ długoterminowej z zapaleniem skóry związanym z nietrzymaniem moczu
}

Ihor Kohut, Svitlana Galnykina

I. Horbachevsky Ternopil National Medical University, Ternopil, Ukraine

Dermatol Rev/Przegl Dermatol 2019, 106, 683-686

DOI: https://doi.org/l 0.5 I |4/dr.2019.92742

Candida albicans is the most prevalent human fungal commensal organism and is reported to be the most frequent aetiological agent of incontinenceassociated dermatitis (IAD). However, it remains unclear whether incontinence predisposes a patient to increased Candida colonisation or whether incontinence acts as a trigger for Candida infection in those already colonised. For this reason, understanding the epidemiology of IAD and accurately estimating Candida colonisation is necessary [1]. Candida infection commonly presents with a central maculopapular rash, characteristic satellite lesions at the margins, non-specific confluent papules, erythematous, and scaly plaques with maceration and oedema, sometimes with pustules and erosion in severe cases [1, 2].

In most cases, laboratory investigations are not necessary, except for mycological cultures of swabs [3]. Superinfection or infection by Candida albicans seem to be so frequent that it may be reasonable to propose a biopsy only when antifungal treatment and routine skin care fail. Biopsy and histopathological examinations are often nonspecific, even in cases of psoriasis or eczema [4].

Treatment goals include protecting the skin from further exposure to irritants, establishing a healing environment, and eradicating any cutaneous infections [5]. The general characteristics of the ideal product for the prevention and management of IAD were formulated in 2015 by the Global IAD Expert Panel. Such a product should be clinically effective and cost effective, have low irritant potential, be compatible with other products used, transparent, and easily removed for skin inspection [6]. After searching for a topical product that would have the impact in the prevention and management of IAD, an official Camphorated oil was proposed for use.
Candida albicans jest najczęściej występującym u ludzi grzybem zaliczanym do organizmów komensalnych. Według dostępnych doniesień jest także głównym czynnikiem etiologicznym zapalenia skóry związanego z nietrzymaniem moczu (incontinence-associated dermatitis IAD). Dotychczas nie ustalono jednak, czy nietrzymanie moczu predysponuje do nasilonej kolonizacji grzybami z rodzaju Candida, czy też stanowi czynnik wyzwalający to zakażenie u osób, u których już wcześniej nastąpiła kolonizacja. $Z$ tego względu niezbędne jest poznanie epidemiologii IAD, a także dokładna ocena kolonizacji Candida [1]. Zakażenie grzybami z rodzaju Candida zazwyczaj objawia się plamisto-grudkową osutką z charakterystycznymi zmianami satelitarnymi na obwodzie, a także nieswoistymi, zlewającymi się grudkami, rumieniowo-złuszczającymi blaszkami z towarzyszącą maceracją skóry i obrzękiem, czasem ze zmianami krostkowymi, a w ciężkim przebiegu także z obecnością nadżerek [1, 2].

W większości przypadków badania laboratoryjne nie są konieczne, z wyjątkiem posiewu mykologicznego wymazów [3]. Nadkażenie lub zakażenie przez Candida albicans jest na tyle powszechne, że biopsja ma uzasadnienie jedynie wówczas, gdy leczenie przeciwgrzybicze i rutynowa pielęgnacja skóry nie przynoszą pożądanego efektu. Badania biopsyjne i histopatologiczne są często nieswoiste, nawet w przypadku łuszczycy lub wyprysku kontaktowego [4].

Cele leczenia obejmują ochronę skóry przed dalszym narażeniem na działanie czynników drażniących, stworzenie środowiska sprzyjającego gojeniu oraz wyeliminowanie ewentualnych zakażeń skórnych [5]. Ogólne właściwości, jakie powinien mieć idealny preparat do profilaktyki i leczenia IAD, zostały określone w 2015 roku przez Globalny Panel Ekspertów ds. IAD. Preparat taki powinien cechować się dobrą skutecznością kliniczną i być ekonomicznie opłacalny oraz wykazywać niski potencjał drażniący i zgodność z innymi stosowanymi 
This study aimed at investigating the efficacy of camphorated oil in the skin care of long-term care residents with IAD.

This prospective, observational study included 134 consecutive adult patients who were hospitalised in long-term care units between July 2014 and March 2017 and were diagnosed with IAD. The mean age was 77 years (range $36-92)$. The cohort included 83 $(61.9 \%)$ women. All patients had urinary incontinence, while 48 residents ( $35.8 \%$ ) had double urinary and faecal incontinence.

Patients with IAD were randomly divided into a study group $(n=104)$ and a control group $(n=30)$. In patients from the study group, local application of camphorated oil at a concentration of $0.1 \mathrm{~g}$ of Camphor racemic in $1 \mathrm{ml}$ of sunflower oil was used to clean and protect their skin from urine and/or stool followed by a diaper change three times a day. In the 30 patients from the control group the routine cleansers, moisturisers, and skin protectants were used in the same skin care regimen.

Pre-treatment (Day 1) and post-treatment (Day 30 \pm 1 ) study evaluations included a complete physical examination with detail description of eruption. Mycological culture swabs were collected from sites with fungal-appearing rash or, when suggestive eruption was absent, from the inguinal skin. Specimens were cultured on Sabouraud agar for yeasts and incubated at $37^{\circ} \mathrm{C}$ for $48-72$ hours to identify Candida spp.

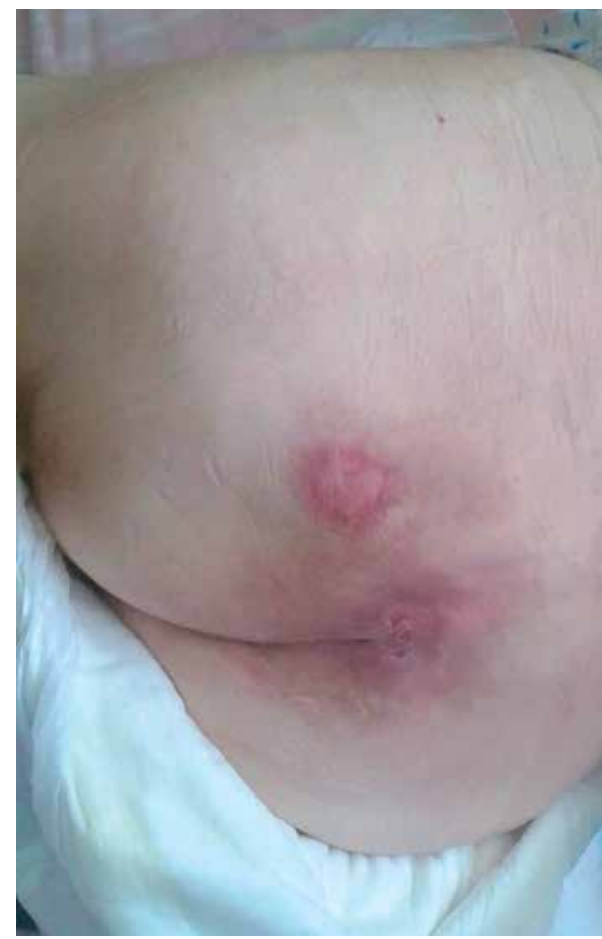

Figure I. Skin before study treatment

Rycina I. Skóra przed podjęciem leczenia objętego badaniem preparatami. Powinien również być przezroczysty i łatwy do usunięcia, co umożliwia kontrolę stanu skóry [6]. Po rozważeniu potencjalnych preparatów miejscowych, które mogłyby przynieść pożądany efekt $\mathrm{w}$ profilaktyce i terapii IAD, zdecydowano się na zastosowanie farmaceutycznego oleju kamforowego.

Badanie ma na celu ocenę skuteczności oleju kamforowego $\mathrm{w}$ pielęgnacji skóry pacjentów opieki długoterminowej z zapaleniem skóry związanym z nietrzymaniem moczu.

Prospektywnym badaniem obserwacyjnym objęto 134 kolejnych dorosłych pacjentów z rozpoznaniem IAD przebywających w placówkach opieki długoterminowej od lipca 2014 do marca 2017 roku. Średnia wieku pacjentów wynosiła 77 lat (przedział: 36-92 lata). Badana grupa obejmowała $83(61,9 \%)$ kobiety. U wszystkich uczestników badania występowało nietrzymanie moczu, a u 48 (35,8\%) pacjentów obecne było nietrzymanie zarówno moczu, jak i kału.

Chorych z IAD podzielono losowo na grupę badaną $(n=104)$ i grupę kontrolną $(n=30)$. U pacjentów z grupy badanej stosowano miejscowo olej kamforowy (w stężeniu $0,1 \mathrm{~g}$ kamfory racemicznej na $1 \mathrm{ml}$ oleju słonecznikowego) do mycia i ochrony skóry przed skutkami styczności z moczem i/lub kałem. Pieluchę zmieniano 3 razy dziennie. U 30 pacjentów z grupy kontrolnej stosowano standardowe preparaty myjące, nawilżające i ochronne w analogicznym schemacie pielęgnacyjnym.

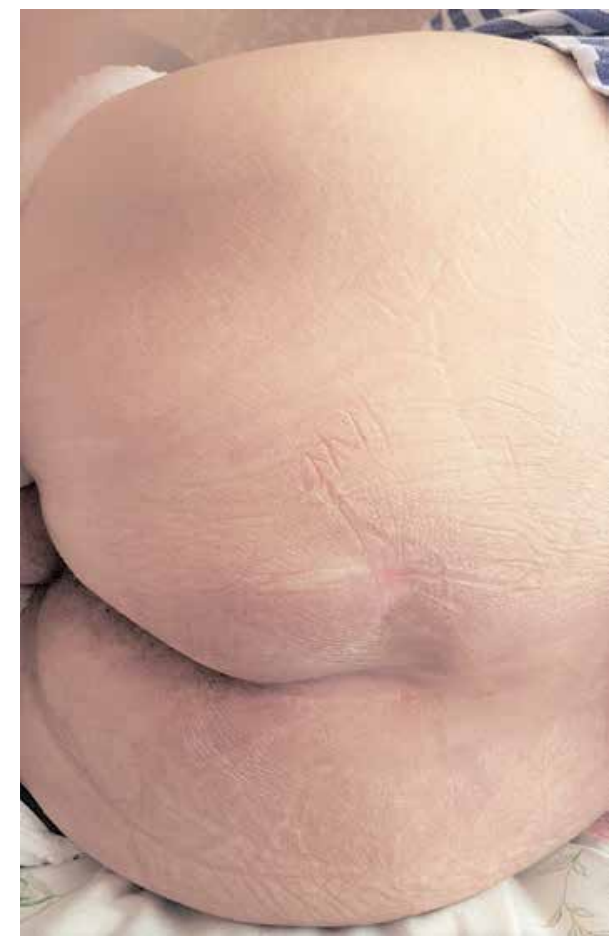

Figure 2. Skin after I-month course of study treatment Rycina 2. Skóra po miesiącu stosowania leczenia 
Data were analysed using Microsoft ${ }^{\circledR}$ Excel $^{\circledR} 2016$ and MedCalc ${ }^{\circledast}$. Variables were described using frequencies, means, and standard deviations. For categorical variables with a binary response (results of cutaneous swab cultures, cases of fungal-appearing rash) bivariate associations were analysed by performing McNemar's $\chi^{2}$ test. Statistical significance was set at $\alpha=0.05$. For variables achieving significance, binomial logistic regression was performed and $95 \%$ confidence intervals (CI) were calculated for the odds ratios (OR).

At the pre-treatment examination, mycological culture swabs revealed Candida spp. in 39 (37.5\%) patients in the study group vs. $11(36.7 \%)$ patients in the control group. Post-treatment contamination by Candida spp. significantly declined to $12(11.5 \%)$ patients $\left(\chi^{2}=24.04 ; p<0.001\right)$ in the study group and to $6(20.0 \%)$ patients $\left(X^{2}=5.00 ; p<0.025\right)$ in the control group.

Fungal-appearing rash was observed in 53 (51.0\%) patients of the study group at the initial examination, which significantly dropped to $33(31.7 \%)$ patients $\left(x^{2}=16.4 ; p<0.001\right)$ after the course of treatment. In the control group, fungal-appearing rash also significantly decreased from $12(40.0 \%)$ to $5(16.7 \%)$ patients $\left(X^{2}=5.4 ; p<0.02\right)$, respectively.

The fungal-appearing rash was confirmed with positive mycological culture swab test in $30(28.8 \%)$ cases of the study group at baseline. Subsequently, at post-treatment examination the rate of eruption with laboratory validated Candida spp. significantly decreased to $8(7.8 \%)$ cases $\left(\chi^{2}=20.05 ; p<0.001\right)$. In the control group the number of patients with mycologically approved rash also declined during the study from $8(26.7 \%)$ to $4(13.3 \%)$, respectively $\left(X^{2}=4.0 ; p=0.046\right)$.

Comparing of the post-treatment rates of mycologically confirmed fungal-appearing rash showed that camphorated oil was significantly superior to routine product in the restraining of yeast colonisation of skin $(\mathrm{OR}=12.5 ; 95 \%$ CI: $1.21-128.67 ; p=0.034)$. The better results in the study group may be explained by the antifungal properties of camphor.

Additionally, economic analysis showed that camphorated oil application for incontinence skin care is 2.5 times less expensive than routine wet wipes 3 in 1 or a combination of cleansing foam and barrier cream.

The studied medication effectively reduced Candida spp. colonisation.

\section{CONFLICT OF INTEREST}

The authors declare no conflict of interest.
Ocena przeprowadzona przed podjęciem leczenia (dzień 1.) i po leczeniu (dzień 30. \pm 1 ) obejmowała kompleksowe badanie przedmiotowe i szczegółowy opis zmian skórnych. Wymazy do posiewów mykologicznych pobrano z miejsc, w których występowały zmiany grzybicze na skórze. W przypadku braku jednoznacznych zmian wymazy pobierano ze skóry w obrębie pachwiny. Próbki hodowano na podłożu Sabourauda dla drożdży i inkubowano w temperaturze $37^{\circ} \mathrm{C}$ przez $48-72$ godzin w celu identyfikacji Candida spp.

Dane analizowano przy wykorzystaniu programów Microsoft $^{\circledR}$ Excel $^{\circledR} 2016$ i MedCalc ${ }^{\circledast}$. Zmienne zostały wyrażone w postaci częstości, średnich wartości i odchyleń standardowych. Dla zmiennych kategorycznych z odpowiedzią binarną (wyniki badań posiewów wymazów skórnych, przypadki zmian grzybiczych na skórze) przeanalizowano zależności dwuwymiarowe za pomocą testu $\chi^{2}$ McNemara. Za poziom istotności statystycznej przyjęto $\alpha=0,05$. Dla zmiennych, które osiągnęły poziom istotności, wykonano dwumianową regresję logistyczną i wyliczono 95-procentowe przedziały ufności (CI) dla ilorazów szans (OR).

$\mathrm{W}$ badaniu poprzedzającym leczenie $\mathrm{w}$ posiewach mykologicznych wymazów wykazano obecność Candida spp. u 39 (37,5\%) pacjentów w grupie badanej i 11 $(36,7 \%)$ pacjentów w grupie kontrolnej. Po zakończeniu leczenia odnotowano istotne zmniejszenie zakażeń Candida spp. do $12(11,5 \%)$ pacjentów $\left(X^{2}=24,04\right.$; $p<0,001) \mathrm{w}$ grupie badanej i $6(20,0 \%)$ pacjentów $\left(x^{2}=5,00 ; p<0,025\right)$ w grupie kontrolnej.

$\mathrm{W}$ badaniu wstępnym zmiany grzybicze na skórze stwierdzono u $53(51,0 \%)$ pacjentów z grupy badanej. Liczba ta zmniejszyła się istotnie do $33(31,7 \%)$ pacjentów $\left(x^{2}=16,4 ; p<0,001\right)$ po zakończeniu leczenia. Także $\mathrm{w}$ grupie kontrolnej liczba pacjentów ze zmianami grzybiczymi na skórze istotnie się zmniejszyła z $12(40,0 \%)$ do $5(16,7 \%)\left(x^{2}=5,4 ; p<0,02\right)$.

Przed wdrożeniem leczenia zmiany grzybicze na skórze potwierdzone dodatnim wynikiem posiewu mykologicznego występowały u $30(28,8 \%)$ osób z grupy badanej. $W$ badaniu przeprowadzonym po leczeniu częstość występowania zmian skórnych z potwierdzoną laboratoryjnie obecnością grzybów z rodzaju Candida spp. zmniejszyła się istotnie do $8(7,8 \%)$ przypadków $\left(X^{2}=20.05, p<0,001\right)$. W grupie kontrolnej liczba pacjentów z potwierdzonymi mykologicznie grzybiczymi zmianami skórnymi również zmniejszyła się podczas badania z $8(26,7 \%)$ do 4 osób $(13,3 \%)$ $\left(x^{2}=4,0 ; p=0,046\right)$.

Porównanie częstości występowania zmian grzybiczych na skórze potwierdzonych wynikiem posiewu mykologicznego przed leczeniem i po leczeniu wykazało, że olej kamforowy cechuje się istotnie wyższą skutecznością pod względem hamowania kolonizacji skóry przez drożdżaki niż standardowe preparaty tego 
rodzaju (OR = 12,5; 95\% CI: 1,21-128,67; $p=0,034)$. Lepsze wyniki w grupie badanej można wyjaśnić właściwościami przeciwgrzybiczymi kamfory.

Ponadto analiza finansowa wykazała, że stosowanie oleju kamforowego w pielęgnacji skóry osób z nietrzymaniem moczu jest 2,5-krotnie tańsze od rutynowo wykorzystywanych do tego celu chusteczek nawilżających typu „3 w 1" lub połączenia pianki czyszczącej i kremu barierowego.

\section{KONFLIKT INTERESÓW}

Autorzy nie zgłaszają konfliktu interesów.

\section{References}

Piśmiennictwo

1. Campbell J., Coyer F., Mudge A., Robertson I., Osborne S.: Candida albicans colonisation, continence status and incontinence-associated dermatitis in the acute care setting: a pilot study. Int Wound J 2017, 14, 488-495.

2. VanDamme N., Van den Bussche K., De Meyer D., Van Hecke A., Verhaeghe S., Beeckman D.: Independent risk factors for the development of skin erosion due to incontinence (incontinence-associated dermatitis category 2 ) in nursing home residents: results from a multivariate binary regression analysis. Int Wound J 2017, 14, 801-810.

3. Bonifaz A., Rojas R., Tirado-Sanchez A., Chavez-Lopez D., Mena C., Calderon L., et al.: Superficial mycoses associated with diaper dermatitis. Mycopathologia 2016, 181, 671-679.

4. Foureur N., Vanzo B., Meaume S., Senet P.: Prospective aetiological study of diaper dermatitis in the elderly. Br J Dermatol 2006, 155, 941-946.

5. Gray M., Beeckman D., Bliss D., Fader M., Logan S., Junkin J., et al.: Incontinence-associated dermatitis: a comprehensive review and update. J Wound Ostomy Continence Nurs 2012, 39, 61-74.

6. Beeckman D., Campbell J., Campbell K., Chimentão D., Coyer F., Domansky R., et al.: Proceedings of the global IAD expert panel. Incontinence-associated dermatitis: moving prevention forward. Wounds Int 2015.

Received: 6.07.2018

Accepted: 7.08 .2019

Otrzymano: 6.07.2018 r.

Zaakceptowano: 7.08.2019 r.

How to cite this article

Kohut I., Galnykina S.: The efficacy of topical camphorated oil in long-term care of residents with incontinence-associated dermatitis. Dermatol Rev/Przegl Dermatol 2019, 106, 683-686. DOI: https://doi.org/10.5114/dr.2019.92742. 